\title{
PENYUSUNAN PROPOSAL PENELITIAN TINDAKAN KELAS (PTK) PADA GURU-GURU SEKOLAH YAYASAN KHOLIFAH MASA DEPAN DEPOK
}

\author{
Anastasia Dewi Anggraeni, Siti Nurani \\ Pendidikan Bahasa Inggris, Fakultas Bahasa dan Seni, Universitas Indraprasta PGRI \\ angelinanasta@gmail.com,rani_siti16@yahoo.com
}

\begin{abstract}
Abstrak
Tujuan dari kegiatan pengabdian masyarakat ini diantaranya adalah sebagai berikut: 1) Memotivasi guru untuk meningkatkan kemampuan dalam melakukan PTK, 2) Memberikan keterampilan langsung untuk melakukan dan melakukan PTK yang praktis, 3) Memberikan pemahaman pada guru akan kebermanfaatan PTK untuk meningkatkan kualitas pembelajaran di sekolah, 4) Melatih para guru agar dapat membuat sendiri proposal PTK, 5) Mengenal Potensi Siswa yang dapat dikembangkan oleh guru untuk meningkatkan hasil belajar mata pelajarannya masing-masing. Pendekatan pelatihan ini secara individual dan klasikal. Metode yang digunakan adalah ceramah, latihan, dan evaluasi. Hasil dari kegiatan abdimas ini, yakni antusias dan motivasi para peserta yang tinggi untuk membuat proposal penelitian tindakan kelas.
\end{abstract}

Kata kunci: proposal, Penelitian Tindakan Kelas (PTK), guru

\begin{abstract}
The purpose of this community service activities are as follows: 1) To motivate teachers to improve their skills in conducting PTK, 2) Providing direct skills to conduct and conduct a practical PTK, 3) Providing an understanding of the teachers of the usefulness of PTK to improve the quality of learning in schools, 4) Train teachers to make their own PTK proposals, 5) Know the Potential of Students that can be developed by teachers to improve the learning outcomes of their respective subjects. This training approach is individual and classical. The methods used are lectures, exercises, and evaluations. The results of this abdimas activity, namely the enthusiasm and motivation of the participants are high to make a classroom action research proposal.
\end{abstract}

Keywords: proposal, Classroom Action Research (PTK), teacher

\section{PENDAHULUAN}

Diberlakukannya Undang-undang RI Nomor 14 Tahun 2005 tentang Guru dan Dosen, merupakan bukti pengakuan terhadap profesionalitas pekerjaan guru dan dosen semakin mantap. Terlebih lagi di dalam pasal 14 dan 15 Undangundang tersebut dinyatakan bahwa guru berhak memperoleh penghasilan di atas kebutuhan hidup minimum dan jaminan kesejahteraan sosial, meliputi gaji pokok, tunjangan yang melekat pada gaji, serta penghasilan lain berupa tunjangan profesi, tunjangan fungsional, tunjangan khusus, dan maslahat tambahan yang terkait dengan tugasnya sebagai guru yang ditetapkan dengan prinsip penghargaan atas dasar prestasi.

Bagi para guru pengakuan dan penghargaan di atas harus dijawab 
dengan meningkatkan profesionalisme dalam bekerja. Setiap kinerjanya harus dapat dipertanggung jawabkan baik secara publik maupun akademik. Untuk itu ia harus memiliki landasan teoretik atau keilmuan yang mapan dalam melaksanakan tugasnya mengajar maupun membimbing peserta didik.

Tuntutan agar guru mampu meneliti semakin gencar dilakukan oleh pemerintah. Hal itu dibuktikan dari laporan portofolio guru yang mensyaratkan melampirkan karya tulisnya dalam sertifikasi guru dalam jabatan karena hal itulah maka guru-guru di sekolah harus dapat meneliti di kelasnya sendiri dengan tujuan memperbaiki kualitas pembelajarannya melalui Penelitian Tindakan Kelas (PTK). PTK sesungguhnya merupakan implementasi dari kreativitas dan kekritisan seorang guru terhadap apa yang sehari-hari diamati dan dialaminya sehubungan dengan profesinya untuk menghasilkan kualitas pembelajaran yang lebih baik sehingga mencapai hasil belajar yang optimal.

Namun, sangat disayangkan masih banyak guru-guru yang belum mengenal dan belum melakukan PTK sama sekali di kelasnya. Sehingga tujuan dari worshop ini adalah mengajak atau memotivasi guru yang masih enggan mengadakan penelitian karena berbagai alasan untuk dapat mengembangkan potensi siswa yang ada di kelasnya. Dengan mengetahui potensi siswa, guru menjadi semakin dekat dengan para siswanya, dan terjadilah proses interaktif di antara guru dan siswa.

Berdasarkan hal tersebut di atas, maka kami selaku tim abdimas berusaha melakukan suatu kegiatan pelatihan PTK yang mengajak para guru untuk aktif menulis, meneliti dan menuliskan laporan penelitiannya sehingga dapat meningkatkan kualitas pembelajarannya di kelas. Disamping materi PTK kami suguhkan materi pendukung yaitu model-model pembelajaran inovatif dan Pengembangan Keprofesiaan Berkelanjutan $(\mathrm{PKB})$ yang tdk terpisahkan dengan PTK itu sendiri.

Dengan latar belakang di atas, maka materi pelatihan penelitian tindakan kelas ini sangat penting untuk dikuasai oleh para guru.

SMA Perjuangan \& Informatika Terpadu-SMK Perjuangan dan Peradaban merupakan sekolah menengah swasta yang terletak di wilayah Pancoran Mas Depok. Berdasarkan hasil monitoring di lapangan, diperoleh informasi bahwa dua sekolah tersebut merupakan sekolah yang bernaung pada satu yayasan bernama Sekolah Perjuangan.

SMA Perjuangan \& Informatika Terpadu memiliki berbagai fasilitas seperti ruang perpustakaan dan ruang laboratorium komputer. Selain fasilitas ruang perpustakaan, dengan konsentrasi penjurusan di bidang farmasi, SMK Perjuangan \& Peradaban memiliki ruang laboratorium untuk siswa melakukan praktik yang berhubungan dengan bidang farmasi. Jumlah tenaga pengajar di SMA Perjuangan \& Informatika Terpadu adalah sebanyak 20 orang, sedangkan jumlah tenaga pengajar yang ada di SMK Perjuangan \& Peradaban adalah sebesar 25 orang yang terdiri dari guru kelas dan guru bidang studi.

Pada tahapan monitoring, diperoleh informasi bahwa siswa di lingkungan SMA dan SMK berasal dari berbagai kalangan, dengan variasi tingkat ekonomi dan sosial. Hal ini tentunya dapat menciptakan keragaman permasalahan yang berdampak pada proses belajar mengajar di kelas. Begitu juga dengan guru-guru di SMA dan SMK Perjuangan yang juga memiliki latar belakang pendidikan dan bidang keilmuan yang berbeda-beda yang dapat menciptakan keragaman pemberian 
metode maupun teknik pengajaran yang sangat bervariasi. Penentuan keberhasilan proses belajar mengajar tidak terlepas dari peran ke dua belah pihak, baik dari sisi siswa maupun sisi guru itu sendiri. Oleh karena itu, tim pelaksana memandang perlu untuk memberikan kontribusi dalam memberikan pelatihan penyusunan proposal Penelitian Tindakan Kelas (PTK) kepada guru dengan harapan dapat memberikan wawasan yang lebih mendalam terhadap pengetahuan penyusunan proposal secara sistematis dan tepat guna sesuai dengan kebutuhan jenjang penelitian di kelas masing-masing yang nantinya akan dapat diterapkan pada kelas yang diampu masing-masing guru.

Berdasarkan informasi yang telah dipaparkan sebelumnya, terdapat beberapa permasalahan yang ditemui di sekolah mitra, antara lain adalah keberagaman disiplin ilmu guru-guru di SMA Perjuangan \& Informatika Terpadu dan SMK Perjuangan \& Peradaban Depok. Lebih lanjut, keberagaman latar belakang sosial dan ekonomi siswa SMA dan SMK juga turut menjadi faktor penentu keberhasilan proses belajar di sekolah. Mitra memliki 45 guru, dimana hanya sebagian kecil yang sudah pernah melakukan Penelitian Tindakan Kelas (PTK) karena kurangnya pengetahuan tentang prinsip dan tata cara pelaksanaan PTK, sementara pelatihan itu pada dasarnya dibutuhkan untuk menunjang profesionalisme serta fungsionalisme guru.

Setiap penelitian idealnya didahului dengan pembuatan usulan penelitian atau proposal penelitian. Proposal penelitian merupakan gambaran singkat tentang pokok permasalahan yang akan diteliti. Dalam proposal penelitian berisikan berbagai hal, seperti latar belakang masalah, perumusan masalah, manfaat dan tujuan di- adakannya penelitian, ulasan singkat tentang bahan teori yang berkaitan dengan masalah tersebut serta menjelaskan metode penelitian yang digunakan. Dengan adanya proposal penelitian, seorang peneliti akan memiliki acuan kegiatan-kegiatan yang seharusnya dilakukan.

Proposal adalah rencana yang disusun utnuk kegiatan tertentu (Hasnun, 2007). Proposal penelitian adalah pedoman yang berisikan berbagai kegiatan serta langkah-langkah sistematis yang akan diikuti oleh seorang peneliti dalam melaksanakan suatu penelitian (Sugiyono, 2013).

Peningkatan mutu pendidikan dapat dicapai melalui berbagai cara antara lain: melalui peningkatan kualifikasi pendidik dan tenaga kependidikan lainnya, pelatihan dan pendidikan, atau dengan memberikan kesempatan untuk menyelesaikan masalah pembelajaran dan non pembelajaran secara profesional lewat penelitian tindakan secara terkendali. Upaya peningkatan kualitas pendidik dan tenaga kependidikan lainnya untuk menyelesaikan masalah yang dihadapi saat menjalankan tugasnya akan memberi dampak positif. Pertama, kemampuan dalam menyelesaikan masalah pendidikan yang nyata akan semakin meningkat. Kedua, penyelesaian masalah pendidikan dan pembelajaran melalui sebuah investigasi terkendali akan dapat meningkatkan kualitas isi, masukan, proses, dan hasil belajar. Ketiga, peningkatan profesionalisme pendidik dan tenaga kependidikan lainnya.

Melalui penelitian tindakan kelas (PTK) masalah pendidikan dan pembelajaran dapat dikaji, ditingkatkan dan dituntaskan, sehingga proses pendidikan dan pembelajaran yang inovatif dan ketercapaian tujuan pendidikan dapat diaktualisasikan secara sistematis. 
Upaya PTK diharapkan dapat menciptakan sebuah budaya belajar (learning culture) di kalangan guru-guru di sekolah. PTK menawarkan peluang sebagai strategi pengembangan kinerja, sebab pendekatan penelitian ini menempatkan pendidik dan tenaga kependidikan lainnya sebagai peneliti, sebagai agen perubahan yang pola kerjanya bersifat kolaboratif (collaborative).

Kegiatan pelatihan penyusunan proposal Penelitian Tindakan Kelas (PTK) yang diberikan kepada guru-guru SMA-SMK Perjuangan diharapkan dapat menambah wawasan guru-guru dalam melaksanakan PTK di kelas dan jenjang sekolah masing-masing. Pelatihan ini pada khususnya diharapkan dapat meningkatkan atau memperbaiki kinerja belajar siswa di sekolah, meningkatkan mutu proses pembelajaran di kelas, meningkatkan kualitas penggunaan media, alat bantu belajar, dan sumber belajar lainnya, meningkatkan, memperbaiki maupun menjaga kualitas prosedur dan alat evaluasi yang digunakan untuk mengukur proses dan hasil belajar siswa. Selain itu, pelatihan juga dimaksudkan untuk membantu guru-guru dalam upaya peningkatan atau perbaikan terhadap masalah-masalah pendidikan anak di sekolah serta peningkatan dan perbaikan terhadap kualitas penerapan kurikulum dan pengembangan kompetensi siswa di sekolah.

Pelatihan pembuatan proposal Penelitian Tindakan Kelas (PTK) sangat dibutuhkan oleh para guru untuk memenuhi kewajibannya sebagai tenaga pendidik. Proposal sendiri berasal dari bahasa inggris, to popose yang artinya mengajukan yang secara sederhana bisa diartikan sebagai bentuk pengajuan atau permohonan.

Penelitian Tindakan Kelas (PTK) sebenarnya merupakan pengembangan dari penelitian tindakan (action research). Kemmis dan Taggart dalam (Legiman, 2015) menerangkan bahwa penelitian tindakan (action research) adalah suatu bentuk penelitian refleksi diri yang dilakukan oleh para partisipan dalam situasi sosial (termasuk pendidikan) untuk memperbaiki praktik yang dilakukan sendiri.

Penelitian tindakan kelas merupakan suatu pencermatan terhadap kegiatan belajar berupa sebuah tindakan, yang sengaja dimunculkan dan terjadi dalam sebuah kelas secara bersamaan (Arikunto, 2006).

Lebih lanjut, menurut Hopkins (Nurizzati, 2014), PTK dapat didefinisikan sebagai bentuk kajian yang bersifat reflektif, yang dilakukan oleh pelaku tindakan untuk meningkatkan kemantapan rasional dari tindakantindakannya dalam melaksanakan tugas dan memperdalam pemahaman terhadap kondisi dalam praktek pembelajaran.

Dari pendapat beberapa pakar pendidikan seperti disampikan di atas, maka dapat disimpulkan bahwa Penelitian Tindakan Kelas adalah penelitian yang dilakukan oleh guru di dalam kelasnya sendiri melalui refleksi diri, dengan tujuan untuk memperbaiki kinerjanya sebagai guru, sehingga hasil belajar peserta didik menjadi meningkat.

\section{METODE PELAKSANAAN}

Agar tujuan tercapai, kegiatan pelatihan PTK ini dilakukan dengan pendampingan agar dapat berjalan dengan lancar maka sebagai alternatif pemecahan masalah adalah sebagai berikut: pendampingan dilakukan dengan pendekatan individual dan klasikal. Pendekatan klasikal dilakukan pada saat pemberian teori tentang cakupan penelitian kelas dan pendekatan individual dilakukan pada saat latihan 
membuat proposal PTK. Adapun metode yang digunakan adalah:

\section{Ceramah}

Metode ini dipilih untuk menyampaikan konsep-konsep yang penting untuk dimengerti dan dikuasai oleh peserta pelatihan. Materi yang diberikan meliputi topik dan langkahlangkah penelitian tindakan kelas.

\section{Latihan}

Metode ini digunakan untuk memberikan tugas kepada peserta pendampingan untuk mempraktikkan pembuatan proposal PTK.

\section{Evaluasi}

Setelah dilakukan pendampingan kepada para peserta, maka dilakukan penilaian atau evaluasi terhadap karya peserta mengenai masalah PTK dan langkah-langkah PTK.

\section{HASIL DAN PEMBAHASAN}

Dengan beragamnya latar belakang pemicu permasalahan belajar siswa, dengan demikian dipandang perlu bagi guru maupun perangkat ajar lainnya untuk berperan aktif mengambil bagian sebagai fasilitator dalam pemberian solusi dalam bentuk nyata. Salah satu upaya guru dalam memberikan solusi masalah belajar siswa adalah dengan melaksanakan Penelitian Tindakan Kelas (PTK). Pelaksanaan PTK merupakan cara yang efektif dalam mengidentifikasi masalah belajar siswa sehingga solusi atas permasalahan tersebut juga dapat secara tepat diberikan kepada siswa. PTK juga mampu menjadi sarana bagi guru untuk dapat segera mengambil tindakan secara menyeluruh terkait permasalahan siswa baik secara akademik maupun non akademik.

Kegiatan pelatihan ini diawali dengan melakukan wawancara terlebih dahulu kepada guru-guru mengenai jenis permasalahan belajar siswa yang sering muncul di kelas. Setelah mengetahui masalah yang sering terjadi di lapangan, kami selaku tim memberikan materi konsep dan langkah-langkah PTK yang kemudian dilanjutkan dengan kegiatan praktek oleh peserta.

Secara garis besar Penelitian Tindakan Kelas ini terdapat empat langkah kegiatan (siklus) yang lazim dilakukan. Menurut Arikunto (2006:16) keempat langkah tersebut adalah (1) perencanaan, (2) pelaksanaan, pengamatan dan (4) refleksi.

Tahap 1: Menyusun Rencana Tindakan (Planning). Dalam tahap ini peneliti menjelaskan tentang apa, mengapa, kapan, dimana, oleh siapa dan bagaimana tindakan tersebut dilakukan. Seperti telah disampaikan di muka, bahwa untuk menjawab pertanyaanpertanyaan tadi maka peneliti minta masukan dari guru, kepala sekolah dan teman sejawat.

Tahap 2: Pelaksanaan Tindakan (Acting). Tahap ke-2 dari penelitian tindakan kelas adalah pelaksanaan yang merupakan implementasi atau penerapan isi rancangan, yaitu melakukan tindakan kelas.

Tahap 3: Pengamatan (observing) Tahap ke-3, yaitu kegiatan pengamatan yang dilakukan oleh peneliti. Sebetulnya sedikit kurang tepat kalau pengamatan ini dipisahkan dengan pelaksanaan tindakan karena seharusnya pengamatan dilakukan pada waktu tindakan sedang berlangsung. Jadi, keduanya berlangsung dalam waktu yang bersamaan.

Tahap 4: Refleksi (Reflecting) Tahap ke-4 merupakan kegiatan untuk mengemukakan kembali apa yang sudah dilakukan. Dalam kegiatan ini peneliti melakukan evaluasi diri atau dengan kata lain peneliti mengadakan "dialog" pada diri sendiri terhadap apa yang telah dilakukannya. Kegiatan 
refleksi ini sangat tepat dilakukan ketika peneliti sudah selesai melakukan tindakan, kemudian hasil refleksi ini digunakan sebagai bahan pertimbangan untuk merencanakan tindakan pada siklus berikutnya.

Evaluasi terhadap kegiatan pelatihan ini dilakukan dengan menilai dan memberi saran untuk peserta merevisi hasil karyanya.

\section{SIMPULAN}

Dari hasil pelaksanaan kegiatan pengabdian kepada masyarakat, diberikan beberapa kesimpulan sebagai berikut:

1. Kegiatan pelatihan ini menumbuhkan motivasi dan antusias guru untuk meningkatkan kemampuan dalam melakukan PTK.

2. Para guru mendapatkan keterampilan langsung untuk melakukan dan melakukan PTK yang praktis.

3. Memberikan pemahaman pada guru akan kebermanfaatan PTK untuk meningkatkan kualitas pembelajaran di sekolah.

4. Mengenal potensi siswa yang dapat dikembangkan oleh guru untuk meningkatkan hasil belajar mata pelajarannya masing-masing.
5. Pelatihan penyusunan proposal PTK memberikan manfaat yang sangat signifikan dalam meningkatkan wawasan guru-guru dalam melaksanakan PTK di kelas dan jenjang sekolah masing-masing sehingga dapat dijadikan sebagai bekal untuk meningkatkan mutu proses pembelajaran siswa di kelas.

\section{DAFTAR PUSTAKA}

Arikunto. (2006). Prosedur Penelitian: Suatu Pendekatan Praktik. Jakarta: Rineka Cipta.

Hasnun, A. (2007). Pedoman dan Petunjuk Praktis Karya Tulis. Yogyakarta: Absolut.

Legiman. (2015). Penelitian Tindakan Kelas. Yogyakarta: Widyaiswara LPMP.

Nurizzati. (2014). Ketertolakan Hasil Penelitian Tindakan Kelas. Jurnal Edueksos Vol III No 1, Januari-Juni, 137.

Sugiyono. (2013). Metode Penelitian Kuantitatif, Kualitatif dan $R \& D$. Bandung: CV. Alfabeta. 